\title{
Microbiological Quality of Ready-To-Eat Foods (Rice and Moimoi) Sold By Food Vendors in Federal Polytechnic Bali, Taraba State Nigeia.
}

\author{
Monday, I. E. ${ }^{* 1}{ }^{1}$ Francis, J. I. ${ }^{1}$ and Mohammad, S. U. ${ }^{2}$ \\ ${ }^{l}$ Department of Science Laboratory Technology, Federal Polytechnic Bali, Taraba State, Nigria. \\ ${ }^{2}$ Optimum Laboratories, Yola, Adamawa State, Nigeria.
}

\begin{abstract}
In this study we assessed the microbiological quality of ready-to-eat foods (rice and moimoi) sold by vendors in Federal Polytechnic, Bali campus, Taraba State. A total of six ready-to-eat food samples were collected from the vending site. The result obtained revealed that total bacterial count ranged from $1.0 \times 10^{2}$ to $8.7 \times 10^{4} \mathrm{cfu} / \mathrm{g}$. Microorganisms isolated include staphylococcus aureus, Escherichia coli, Klebsiella spp, Salmonella spp, Mucor spp and Aspergillus spp. The study showed that ready-to-eat foods (rice and moimoi) sold by vendors in Federal Polytechnic, Bali campus were contaminated with various microorganisms indicating inadequate processing and poor handling practices which can pose danger to the health of the consumers. Based on the specification by the international commission for microbiological specification for foods (ICMSF), the level of contamination was within acceptable and tolerable microbiological limits. There was a significant difference $(P<0.05)$ of microbial load between rice and moimoi. However, a closer and stringent supervision of ready-to-eat foods sold to staff and students in the polytechnic campus should be carried out by the relevant authorities to prevent possible outbreak of foodborne illness. Furthermore, health education to improve the knowledge of food vendors on food safety and hygiene practices is imparative.
\end{abstract}

Keywords: Food vendors, Hygienic practices, Microbiological quality, Microorganisms, Ready-to-eat foods.

\section{Introduction}

Microbiological quality of food indicates the amount of microbial contaminants it has, ahigh level of contamination indicates low quality of food storage and its handling more likely to transmit diseases (Oranusi et al., 2013). Bacterial count in prepared food and water is a key factor in assessing the quality and safety of food. It also reveals the level of hygiene adopted by food handlers in the course of preparation of such foods. Food and water in particular have been described as vehicle for the transmission of microbial disease among which are those caused by coliforms (Nkere et al., 2011).

Ready-to-eat foods can be described as foods and beverages that can be bought directly from street vendors or hawkers and are consumed at the point of sale or at later time without further processing. It could be raw or cooked, hot or chilled and can be consumed without further treatment (Tsang, 2002). Examples of such ready-to-eat foods among others include meat pie, burger, coleslaw, fried chicken, milk and milk products, Porridge, rice, and moi moi. While it is expected that the nutritional needs of the consumers should be met via the consumption of street food, it is also necessary to ensure its safety from contaminants and microorganisms.

Safe food is a basic human right despite the fact many foods are frequently contaminated with naturally occurring pathogenic microorganisms which cannot be detected organoleptically (seen, smelled or tested) but can cause diseases including death especially if the way they are conserved during exposition for sale provides condition for those microorganisms to grow and reach considerable levels of contamination (WHO, 2000).

There are many reasons why people eat away from home. These include among others absence from home while travelling, studying, while at work or need for a change in terms of food type or location and as such, many people resort to buying street vended food which may be poorly processed. This situation however, has resulted to the transfer of food sanitary measures and proper food handling from individuals/families' to the food vendors who rarely enforce such practices (Musa and akande, 2002).

An estimated 2.5 billion people patronize food-vendors worldwide ( Nyarango et al., 2003). Foodborne illness is a major international health problem with consequent economic reduction (Duff et al., 2003). According to Doyele and Evans (1999), food borne diseases are diseases resulting from ingestion of bacteria, toxins and cells produced by microorganism present in food. Once the bacterial have produce toxin, the food can be extensively and properly cooked, killing the bacteria without destroying the toxin. Many of their toxins are gene-based that is carried on plasmids (Nwinyiet al., 2009). Bacteria such as Salmonella specie, Escherichia coli and Staphylococcus aureus can cause food poisoning and other food-borne diseases such as tuberculosis, typhoid fever and cholera (Foskett et al., 2003). Some symptoms of food borne illness among others include stomach pain, diarrhoea, vomiting, Nausea and headache. The global incidence of food borne diseases is 
difficult to estimate but it has been reported that in 2000 alone, 2.1 million people died from diarrheal diseases. A great proportion of these cases can be attributed to contamination of food and drinking water (WHO, 2000). In United States, it has been estimated that seven pathogens found in animal product such as Escherichia coli 0157:H7, listeria monocytogenes, Campylobacteria jejuni, Clostridium perfringes, Salmonella spp., Toxoplasma gondii and Staphylococcus aureus account for approximately 3.3-12.3 million cases of food borne illnesses and a record of 3900 deaths each year (Talaro et al., 1996; Buzby et al., 1997). Scharff (2010) estimated that the total cost of food borne illness in USA is almost $\$ 152$ billion per annum.

In Nigeria, there has been an increase in the consumption of ready-to-eat foods over the last few years because they are relatively cheap, easily accessible and convenient. Also, they are easily available, affordable, provides divers/variable food source, employment and with a potential for improving food security and national status and general social security (Draper, 1996). Most people are very much interested in satisfying their hunger and the convenient of ready-to-eat foods rather than its Microbiological quality and hygiene. The fact that Ready-to-eat food is an indispensible part of urban and rural diets, it has its own associated health problems. Since it does not require any further processing before consumption, street-food can be a good vehicle for the transmission of food-borne microorganisms.

Most Ready-to- eat foods in Kumasi, Ghana were reported to be contaminated with enteric bacteria, and had bacteria counts higher than the acceptable levels (Felgo et al., 2012). The microbial safety of Ready-toeat food sold along Onitsha-owere high way south east Nigeria was investigated by Oranusi etal., (2012) and investigation revealed that though some of the studied foods were contaminated beyond acceptable microbiological limits, most were of acceptable microbiological standard.

According to WHO (1989), food handling personnel play a very important role in ensuring food safety through-out the chain of food processing, storage and preparation. Street vended food is controlled by relevant authorities via physical and medical screening of potential food vendors before being issued with certificates and are allowed to Ply their trade. Food vendors are screened for communicable diseases and declared medically fit by medical authorities but this is not so with so many food vendors around the world. In Accra-Ghana, it was revealed in a study involving fifty street vendors that only $40 \%$ possessed health certificates which authorized them to sell food (Ackah etal., 2011).In a related study, in Nigeria by Musa and Akande (2002), only 30 out of 141 of food vendors in secondary schools at illorin had undergone medical examination to be issued with health certificates. Furthermore, a study by (Isara et al., 2010) shows that less than half of the food vendors studied in Benin City, Nigeria had undergone training in food hygiene and safety. These cases of lack of medical certificate for fitness and training on food safety and hygiene may be attributed to the notion held by most people that a person does not need any certificate of medical fitness or any formal training before preparation and sale of food. Also most of the vendors have either no formal education or few years of schooling and therefore lack knowledge on how to handle food and their role in the transmission of pathogen (mensah et al., 2002).

Majority of staff and students on campus don't prepare food themselves or take it along with them to the campus and this led to an increase in demand for food which gives opportunity to cafeterias and canteens to serve as the major vending sites were both staff and students purchase food daily and in most cases these foods are not adequately processed, protected from flies and usually refrigeration is unavailable.

This unhygienic condition under which food vendors operate couple with their lack of basic hygienic safety led to the present study. This study was designed to assay the present microbial quality of ready-to-eat foods sold in Federal Polytechnic Bali, Taraba state Nigeria with a view to proffering solutions for effective preparation and handling of food by the vendors.

\section{Study Area}

\section{Materials And Method}

The study area was the food vending site of the Federal Polytechnic Bali, Taraba state Nigeria.

\section{Sample Collection}

A total of six samples comprising of three each of the two ready-to-eat foods (white rice and moimoi) were randomly obtained from the food vending site of the polytechnic. The samples were collected into sterile specimen container over a two weeks period between the month of January and February, 2014. Samples were purchased when freshly prepared and were immediately transferred in cooled packs, under aseptic condition to the Department of Science Laboratory Technology, Federal Polytechnic Bali, for microbiological analysis within one hour of collection.

\section{Sample analysis}

Ten (10) grams of each food sample was homogenized with $90 \mathrm{ml}$ sterile normal saline. Further ten-fold serial dilutions of the resultant homogenates were made to obtain $10^{-2}, 10^{-3}, 10^{-4}$ and $10^{-5}$ respectively. From the 
appropriate dilutions, $0.1 \mathrm{ml}$ was plated in replicate onto deferent media using pour plate technique. Nutrient agar, Eosin Methylene Blue and Mannitol salt agar (all of Oxoid grade) were inoculated for Total aerobic plate count, Coliform count and isolation of staphylococcus aureus respectively. Sabouraud - Dextrose agar (Fluka) was used for isolation of fungi while Salmonella Shigella agar(Fluka) was inoculated after 24hrs pre-enrichment of sample homogenates in selenite-F broth, for isolation of Salmonella. All inoculated plates were incubated at $37^{\circ} \mathrm{C}$ for $24-48 \mathrm{hrs}$ except, however, Sabouraud-Dextrose agar plates that were incubated at $28^{\circ} \mathrm{C}$ for $72 \mathrm{hrs}$. At the end of the incubation periods, colonies were counted using illuminated colony counter (Gallenkamp, Englang). The counts for each plate were expressed as colony forming unit per $\mathrm{ml}$ of sample homogenate $(\mathrm{cfu} / \mathrm{ml})$. Morphological attributes of the colonies on the media were observed, discrete colonies on the different media were isolated and purified by repeated sub-culturing on nutrient agar. Pure cultures were stored on agar slants at $4^{\circ} \mathrm{C}$ for further characterization.

\section{Coliform test}

Presumptive test: One (1) $\mathrm{ml}$ of each sample homogenate was transferred to sterile test tubes containing Lactose broth and inverted Durham tubes. Incubation was for $24-48 \mathrm{hrs}$ at $37^{\circ} \mathrm{C}$ before tubes were checked for gas production.

Confirmatory test: A loop full of inoculum from the gas positive tubes was streaked onto Eosin Methylene Blue agar plates. Incubation was at $37^{\circ} \mathrm{C}$ and $44^{\circ} \mathrm{C}$ for $24 \mathrm{hrs}$. After incubation, colonies which showed bluish black colour with green metallic sheen and reddish/brown colonies were noted and isolated on agar slants.

Completed test: Colonies which formed green metallic sheen on Eosin Methylene Blue agar, were sub cultured into tubes containing lactose broth and incubated at $37^{\circ} \mathrm{C}$ for $24 \mathrm{hrs}$ after which the tubes were observed for gas production (Oranusi etal., 2004).

\section{Identification of isolates}

The bacterial isolates were identified based on standard microbiological methods of Cowon, (1985) and Speck, (1976). Cultural characteristics such as shape, colour, size and consistency was carried out; Isolates were Gram stained and appropriate biochemical tests performed which include Catalase activity, Sugar utilization, Indole test, Methyl red and Voges Proskauer test, Oxidase test, Motility test, Urease test and Coagulase activity. Fungal isolates were identified based on their macroscopic and microscopic characteristics with reference to standard identification keys and atlas (Fawole, et al., 1986; Tsuneo, 2010).

\section{Statistical analysis}

The data obtained were analyzed using the SPSS (Statistical Package for the Social Sciences) software, version 11.5. Student's t-test was used for comparing the relationships between the variables. Statistical significance was set at $\mathrm{P}<0.05$ (Snedecor, etal., 1976).

\section{Result}

The study revealed that the total bacterial count obtained from these food samples (Rice and Moimoi) under study ranged from $1.0 \times 10^{2}-8.7 \times 10^{4} \mathrm{cfu} / \mathrm{g}$ (Table 1). Rice had a total bacterial counts range of $1.1 \mathrm{x}$ $10^{2}-4.5 \times 10^{4} \mathrm{cfu} / \mathrm{g}$ while that of moimoi had a total bacteria count range of $1.0 \times 10^{2}-8.7 \times 10^{4} \mathrm{cfu} / \mathrm{g}$ (Table 1).

On Nutrient agar, moimoi sample (M1-M3) had higher number of cells ranging from $4.0-8.7 \times 10^{4}$ $\mathrm{cfu} / \mathrm{g}$ followed by rice(R1-R3) with bacteria population of $3.0-4.5 \times 10^{4} \mathrm{cfu} / \mathrm{g}$. Rice sample (R1-R3) had higher number of counts on Eosin Methylene Blue ager $\left(2.7-8.7 \times 10^{3} \mathrm{cfu} / \mathrm{g}\right)$ followed by moimoi (M1-M2) with cells ranging from $1.8-4.5 \times 10^{3} \mathrm{cfu} / \mathrm{g}$. On Mannitol Salt ager, moimoi sample (M1-M2) recorded high bacteria cell density of $1.0-3.5 \times 10^{2} \mathrm{cfu} / \mathrm{g}$ and rice sample (R2-R3) had a count of $1.1-2.0 \times 10^{2} \mathrm{cfu} / \mathrm{g}$ except however, R1 which recorded no growth and this could be due to relative absence of microorganisms in the sample (Table 1). Six genera of different organism were isolated from the samples including Escherichia coli, Staphylococcus aureus, Klebsiella spp, Salmonella spp, Mucor spp and Aspergillus spp indicating that the food samples were contaminated with mixed microbes(Table 2). Also, the presence of these organisms in ready- to- eat foods depicts a deplorable state of poor hygienic and sanitary practices employed in the processing and handling of these foods. 
Table 1: Mean total aerobic bacteria counts (cfu/g) of various food sample

\begin{tabular}{|lccc|}
\hline Food Samples & Nutrient Agar & Eosin Methylene Blue Agar & Mannitol Salt Agar \\
\hline R1 & $4.5 \times 10^{4}$ & $8.7 \times 10^{3}$ & NG \\
R2 & $3.9 \times 10^{4}$ & $5.4 \times 10^{3}$ & $1.1 \times 10^{2}$ \\
R3 & $3.0 \times 10^{4}$ & $2.7 \times 10^{3}$ & $2.0 \times 10^{2}$ \\
M1 & $8.7 \times 10^{4}$ & $4.5 \times 10^{3}$ & $1.0 \times 10^{2}$ \\
M2 & $7.2 \times 10^{4}$ & $3.7 \times 10^{3}$ & $3.5 \times 10^{2}$ \\
M3 & $4.0 \times 10^{4}$ & $1.8 \times 10^{3}$ & $2.0 \times 10^{2}$ \\
\hline
\end{tabular}

$\mathrm{NG}=$ No growth. $\quad \mathrm{R} 1, \mathrm{R} 2, \mathrm{R} 3=$ Rice from vendor 1, 2 and 3. $\quad$ M1, M2, M3= Moimoi from vendor 1, 2 and 3.

Table 2: Microbial isolates from food samples.

\begin{tabular}{|ll|}
\hline Food samples & \multicolumn{1}{c|}{ Organisms isolated } \\
\hline Rice & Escherichia coli, Klebsiella spp, Salmonella spp \\
& Aspergillus spp, Staphylococcus aureus. \\
Moimoi & Staphylococcus aureus, Salmonella spp, Escherichia coli, \\
& Mucor spp. \\
\hline
\end{tabular}

\section{Discussion}

In this study, the total aerobic plate count obtained ranged between $1.0 \times 10^{2}-8.7 \times 10^{4} \mathrm{cfu} / \mathrm{g}$. Earlier works by Oranusi et al., (2013) also reported similar high bacterial population in fried and jollof rice, coleslaw and moimoi. The International Commission for Microbiological Specification for Foods (ICMSF, 1996) states that ready-to-eat foods with plate count between $0-10^{3}$ is acceptable, between $10^{4}-\leq 10^{5}$ is tolerable and $10^{6}$ and above is unacceptable. Hence, foods (rice and moimoi) provided to students by vendors in Federal Polytechnic, Bali campus are of acceptable and tolerable microbiological quality.

However, the significant difference $(\mathrm{p}<0.05)$ observed in the level of microbial contamination in rice and moimo could be associated with inadequate handling and processing by vendors, contamination caused by storage facilities, either poor hygiene or poor quality of grains and water used (Table 1). Similarly, the extensive mixing during processing could have introduced contaminants via food handlers, cooking utensils and from the environment.

According to Bibeki (2001), contamination of food items by specific species of microorganisms is largely due to the presence of these organisms and their entrance into food or beverage as a result of poor hygiene and sanitation. The isolation of Klebsiella spp, staphylococcus aureus, E. coli, Salmonella spp, Mucor spp and Aspergillus spp corroborate the findings of Oranusi etal., 2013; Taulo etal., 2008 in which these organisms were implicated in ready-to-eat foods.

It is necessary that food must be free from contamination as much as possible. The presence of Staphylococcus aureus is largely as a result of human contact and this suggest poor hygiene practices of the vendors since the organism is a normal flora of the skin and nasal passage (Garret, 1988; Nichols etal., 1999). E. coli and Salmonella spp are especially of fecal origin and have been implicated in numerous food borne diseases (Eni, etal., 2010; Oranusi, etal., 2007). However their presence is an indication of possible fecal contamination of food, water or food workers and poor hygienic processing practices (Little et al., 1998; Tambeker et al., 2007). The occurrence of Mucor spp and Aspergillus spp could be due to the fact that they are spore formers and their heat resistant spores may have survived processing while vegetative cells were eliminated. Contamination of food may have resulted from inappropriate processing, incomplete heating or secondary contamination through contact with contaminated equipment and utensils (Oranusi, etal., 2013).

\section{Conclution}

Our findings revealed that Ready-to-eat foods ( Rice and Moimoi) sold in Federal Polytechnic Bali campus were contaminated with various microorganisms; this indicate inadequate processing and poor handling practices which can pose health risk to the consumers. However, Good Manufacturing Practices (GMP) and Hazard Analysis Critical control Point (HACCP) application in the chain of food production and processing as well as health education to improve the knowledge of food vendors on food safety and hygienic practices should be encouraged. 


\section{Acknowledgement}

The authors are grateful to the Department of Science Laboratory Technology, Federal Polytechnic Bali, Taraba State Nigeria, for providing the necessary facilities used in this study. The Management of Optimum Laboratories Yola, Adamawa State Nigeria, are also thanked for their contribution in this research work.

\section{Reference}

[1]. S.U. Oranusi, O.I. Oguoma, E. Agusi, Microbiological quality assessment of foods sold in students cafeterias, Global Research Journal of Microbiology, 3(1), 2013, 1-7.

[2]. K.N. Chukwuemeka, I.I. Nnenne and U.I. Christian, Bacteriological quality of foods and water sold by vendors and in restaurants in Nsuka, Enugu State, Nigeria: A comparative study of three Microbiological methods, Journal of Heath Population and Nutrition, 29(6), 2011,560-566

[3]. D. Tsang, Microbiological Guidelines for ready to eat foods, Road and Environmental Hygiene Department, Hong Kong, 2002,115116.

[4]. World Health Organization, Food borne diseases; A focus for health education, $53^{\text {rd }}$ world health assembly, Geneva, 2000.

[5]. O.I Musa and T.M Akande, Effect of health education intervention or food safety practices among food vendors in illorin, Sahel Medical Journal, 5: 2002, 120-124.

[6]. R.M. Nyakoro, P.A. Aloo, E.W. Kabiru, B.O. Nyanchongi, The risk of pathogenic intestinal parasite infection in Kisii municipality, Kenya, BMC, Public Health, 8: 2003, 237.

[7]. S.B. Duff, E.A. Scott, M.S. Mastilios, E.C. Todd, L.R.G. Krilov, A.M. Eddes, S.J. Acknerman, Cost effectiveness of a target disinfection program in household Kitchens to prevent food borne illness in the United State, Canada and the United Kingdom, J. food protect.bb(11), 2003, 2103-2105.

[8]. M.P. Doyle, P.D. Evans, Foodborne Pathogens of recent concern, Ann. Revised Nutr. 6: 1999, 25-41

[9]. S.C. Yah, C.O. Nwinyi, N.S. Chinedu, Assessment of bacteriological quality of ready to eat food(Meat Pie) in Benin City Metropolis, Nigeria,African Journal of Microbiological Reserch, 3(6), 2009, 390-395.

[10]. P. Foskett, V. Ceserani and R. Kinton, The theory of catering $10^{\text {th }}$ ed. (Hodder and Stoughton: London, 2003, 531).

[11]. K. Talaro, A. Talaro, Foundations in Microbiology, $2^{\text {nd }}$ ed. (Mc Graw Hill Publishers, U.S.A, 1996, 840-841).

[12]. J.C. Buzby, T. Roberts, Economic cost and trade impacts of Microbial Food borne illness: World Health Statistics Quarterly, 50(1/2),1997,57-66.

[13]. R. Scharff, Health-related cost from food borne illness in United States. 2010, Available from: http://www.producesafetyproject.org/admin/assets/files/Health-Related foodborne-ilness-Report.pdflpdf.

[14]. A. Draper, Street foods in developing countries: The potential for micronutrient fortification. John Snow, INC/OMNI project London School of Hygiene And Tropical Medicine, 1996.

[15]. P. Feglo and K. Saki, Bacterial contamination of street food in Kumasi, Ghana, Journal of Medical and Biomedical Science, 1(1), 2012, 1-8.

[16]. U.S. Oranusi and W. Baride, A study of microbial safety of ready-to-eat foods vended on highways; Onitsha-oweri, South East Nigeria, Int. Res. J. Microbiol (IRJM), 3(2), 2012, 066-071.

[17]. World Health Organisation, Health surveillance and Management procedures for food handling personnel, WHO Technical Report Services, 785, Geneva, 1989, 52.

[18]. M. Ackah, E.T. Gyamfi, A.K. Anim, J. Osei, J.K. Hasnsen and O. Agyemang, Socio-economic profile, Knowledge of hygiene and food safety practices among street food vendors in some parts of Accra-Ghana, Internet Journal of food safety, 13, 2011, 191-197.

[19]. A.R. Isara, E.C. Isah, P.V.O. Lofor and C.K. ojide, Food contamination in fast food restaurants in Benin City, Edo State, Nigeria: Implications for food hygiene and safety. Public Health, 124, 2010, 467-471.

[20]. P. Mensah, D. Yeboah-Mann, K. Owusu-Darko and A. Ablordey, Street foods in Accra, Ghana: How safe are they? Bulletin: World Health Organisation, 80(7). 2002, 546-554.

[21]. S. Oranusi, E. Onyeike, M. Galadima, V.J. Umoh, Hazard analysis critical control points of foods prepared by families in Zaria, Nigeria, Nig. J. Microbiol. 18(1-2), 2004, 346-362.

[22]. S.T. Cowan, Cowan and Steel's manual for identification of medical bacteria ( Cambridge University press; Cambridge, 1985)

[23]. M.L. Speck, Compendium of Methods for microbiological Examination of foods. American Public Health Association, Washington DC, 1976, 277-328.

[24]. M.O. Fawole, B.A. Oso, Laboratory Manual of Microbiology( Spectrum books Ltd, Nigeria, 1986) 34-35.

[25]. W. Tsuneo, Pictorial atlas of soil and seed fungi: Morphology of cultural fungi and key tospecies, $3^{\text {rd }}$ ed.( CRC Press, 2010).

[26]. G.W. Snedecor, W.C. Cochran, Statistical methods (The Iwoa State Collage Press, Ames, Iwoa, USA. 1987).

[27]. International Commission for Microbiological Specifications for Foods (ICMSF), Microorganisms in foods 5: Microbiological Specifications of Pathogens, 1996.

[28]. R. Bibek, Fundamental Food Microbiology $2^{\text {nd }}$ edn. (The CRC Press Ltd Washington, DC 2001, 56-90).

[29]. S. Taulo, A. Wetlesen, R. Abrahamsen, R. Mkakosya and G. Kululanga, Microbiological quality of water, associated management practices and risk at source, transport and storage points in a rural community of Lungwena, Malawi, Afr. J. Microbiological Research, 7(2), 2008, 131-137.

[30]. E.S. Garret, Microbiological Standards, guidelines, Specifications and inspection of seafood products. Food Technology,42, 1988, 90-91.

[31]. S.L. Nichols, C.L. Little, V. Mithani, and J. de Louvois, The Microbiological quality of cooked rice from restaurants and take-away premisis in the United Kingdom, Journal of Food protection,62, 1999, 877-882.

[32]. A.O. Eni, I.A. Oluwawemitan and U.S. Oranusi, Microbial quality of fruits and vegetables sold in Sango Ota, Nigeria. Afr. J. Food Sci. 45(5), 2010, 291-296.

[33]. S. Oranusi, M. Galadima, V.J. Umoh and P.I. Nwanze, Food Safety evaluation in boarding schools in Zaria, Nigeria, using the HACCP system, Scientific Research and Essay 2(10), 2007,426-433.

[34]. C.L. Little, H.A. Monsey, G.L. Nichols, and J. de Louvois, The Microbiological quality of ready-to-eat dried fermented meet and meat products, International journal of environmental Health Research, 8,1998, 277-284.

[35]. D.H. Tambekar, S,D. Shirsat, S.B. Suradkar, P.N. Rajanka and Y.S. Banginwar, Prevention of transmission of infectious diseases: Studies of hand hygiene in Health-care among students,Continental journal of Biomedical Sciences, 1, 2007, 6-10. 